\title{
POLA KEHILANGAN GIGI PADA MASYARAKAT DESA ROONG KECAMATAN TONDANO BARAT MINAHASA INDUK
}

\author{
${ }^{1}$ Yuriansya Mangkat \\ ${ }^{2}$ Vonny N. S. Wowor \\ ${ }^{3}$ Nelly Mayulu \\ ${ }^{1}$ Kandidat Skripsi Program Studi Pendidikan Dokter Gigi Fakultas Kedokteran \\ ${ }^{2}$ Program Studi Pendidikan Dokter Gigi Fakultas Kedokteran \\ ${ }^{3}$ Bagian Gizi Fakultas Kedokteran \\ Universitas Sam Ratulangi Manado \\ E-mail:mangkaty@gmail.com
}

\begin{abstract}
The use of denture aims to improve the function of mastication, restoring the aesthetic function, improve the function of phonetics, and maintain the remaining oral tissues to be healthy. This study aimed to obtain the pattern of tooth loss among people in Tondano District Roong Village West. The study population was the whole villagers of Roong who used removable partial dentures acrylic-based. There were 75 people obtained by a preliminary survey in October 2014. Sampling was conducted by using total sampling method. The results showed that tooth loss occured mostly of the lower jaw partly tooth loss (80.33\%). The mostly used type was RPDs with a total of $50.43 \%$ (17.10\% of the upper jaw, 33.33\% of the lower jaw). The pattern of partly tooth loss was based on the Applegate-Kennedy clasification, and the most frequent was class VI 22.10\% (32.14\% of the upper jaw and lower jaw 16.33\%). RPDs were use based on the pattern of tooth loss, the most frequent was class VI $22.10 \%$ (32.14\% RPDs of the upper jaw and $16.33 \%$ of the lower jaw). Based on the pattern of tooth loss, the usage of GTC was most frequent of the class IV 27.27\% (GTC maxilla 1 (5.55\%).
\end{abstract}

Keywords: pattern of tooth loss

\begin{abstract}
Abstrak: Penggunaan gigi tiruan bertujuan untuk memperbaiki fungsi pengunyahan, memulihkan fungsi estetik, meningkatkan fungsi fonetik, serta mempertahankan jaringan mulut yang masih ada agar tetap sehat. Penelitian ini bertujuan untuk mendapatkan gambaran pola kehilangan gigi pada masyarakat Desa Roong Kecamatan Tondano Barat. Populasi penelitian yaitu seluruh masyarakat desa Roong yang menggunakan gigi tiruan sebagian lepasan berbasis akrilik yang berjumlah 75 orang, diperoleh berdasarkan survei awal pada bulan Oktober 2014. Pengambilan sampel dilakukan dengan menggunakan metode total sampling. Hasil penelitian memperlihatkan bahwa pada kehilangan gigi kebanyakan terjadi pada rahang bawah kehilangan gigi sebagian sebanyak 80,33\%. Penggunaan terbanyak jenis GTSL dengan jumlah 50,43\% (rahang atas 17,10\%, rahang bawah 33,33\%). Pola kehilangan gigi sebagian berdasarkan klasifisikasi Applegate-Kennedy, terbesar kelas VI sebanyak 22,10\% (rahang atas 32,14\% dan rahang bawah 16,33\%). Penggunaan GTSL berdasarkan pola kehilangan gigi, terbesar kelas VI sebanyak 22,10\% (GTSL rahang atas 32,14\% dan rahang bawah 16,33\%). Penggunaan GTC berdasarkan pola kehilangan gigi, terbesar kelas IV sebanyak 27,27\% (GTC rahang atas 1 orang yaitu 5,55\%).
\end{abstract}

Kata kunci: pola kehilangan gigi 
Gigi memiliki peran dan fungsi yang sangat penting, Fungsi gigi yaitu untuk mastikasi (pengunyahan), estetik (keindahan), dan fonetik (bicara). Kesehatan rongga mulut serta organ gigi di dalamnya memegang peranan penting dalam kondisi kesehatan individu secara umum. Kondisi kesehatan gigi geligi serta jaringan penunjangnya akan turut menentukan kesehatan rongga mulut secara keseluruhan termasuk kondisi kesehatan secara umum. Keadaan mulut yang buruk akibat banyaknya gigi yang hilang dan tidak diganti dengan gigi tiruan akan mengganggu fungsi dan aktifitas rongga mulut, sehingga dapat memengaruhi status gizi dan berdampak pada kualitas hidup. ${ }^{1}$

Berdasarkan datapenelitiankesehatan nasional yang termuat dalam hasil Riskesdastahun 2010, indeks kehilangan gigi di Indonesia sebesar 79,6\% dan indeks penggunaan protesa sebesar 4,5\%. ${ }^{2}$ Kondisi yang tidak berimbang ini menunjukkan bahwa jumlah individu yang menggunakan gigi tiruan untuk menggantikan giginya yang hilang belum sesuai yang diharapkan. Idealnya kondisi yang ada berimbang antara jumlah individu yang kehilangan gigi dan jumlah individu yang menggunakan gigi tiruan.

Kehilangan gigi-geligi disebabkan oleh faktor penyakit seperti karies dan penyakit periodontal. Faktor bukan penyakit seperti gaya hidup dan faktor sosio-demografi juga berpengaruh terhadap kehilangan gigi. $^{3}$ Kehilangan gigi-geligi meningkat seiring dengan bertambahnya usia akibat efek kumulatif dari karies dan penyakit periodontal. $^{4}$

Pola kehilangan gigi adalah struktur kehilangan gigi yang diklasifikasikan atas kehilangan gigi sebagian dan kehilangan seluruh gigi. Kehilangan gigi baik sebagian atau seluruhnya merupakan indikator kesehatan mulut suatu populasi. Jumlah kehilangan gigi merupakan penilaian dari sukses atau tidak suatu prosedur pencegahan dan perawatan kesehatan gigigeligi. $^{3}$

Kehilangan gigi sebagian yang tidak digantikan dapat memberi dampak berupa migrasi dan rotasi gigi asli yang masih ada, erupsi berlebih pada gigi antagonis, penurunan efisiensi kunyah, gangguan pada sendi temporomandibular, beban berlebih pada jaringan pendukung, gangguan bicara, estetis yang buruk, terganggunya kebersihan mulut, atrisi, dan efek yang tidak diinginkan pada jaringan lunak. Karena itu perawatan pembuatan gigi tiruan sangat dibutuhkan untuk menggantikan gigi asli yang hilang dengan suatu alat tiruan menyerupai gigi asli dan jaringan sekitarnya. ${ }^{5}$ Penggunaan gigi tiruan selain untuk mencegah hal-hal buruk di atas, juga bertujuan untuk memperbaiki fungsi pengunyahan, memulihkan fungsi estetik, meningkatkan fungsi fonetik, serta mempertahankan jaringan mulut yang masih ada agar tetap sehat.

Gigi tiruan dibagi atas dua jenis, yaitu gigi tiruan lepasan dan gigi tiruan cekat. Gigi tiruan lepasan terdiri atas gigi tiruan penuh (GTP) dan gigi tiruan sebagian lepasan (GTSL), sedangkan gigi tiruan cekat (GTC) adalah gigi tiruan jembatan.,6 Pemilihan jenis gigi tiruan yang dibutuhkan oleh seorang pasien disesuaikan dengan jumlah elemen gigi yang hilang, kondisi jaringan pendukung gigi tiruan, lokasi gigi yang hilang, usia pasien, kesehatan sistemik pasien, keinginan dan kebutuhan pasien. Pada kenyataannya seringkali terjadi gigi tiruan yang dibuat belum bisa memenuhi harapan pasien, sehingga banyak muncul keluhan atau ketidakpuasan pasien.

Banyak hal yang dapat memengaruhi kepuasan pasien dalam penggunaan gigi tiruan, di antaranya keberhasilan gigi tiruan menggantikan fungsi gigi yang hilang. Salah satu penentu keberhasilan perawatan gigi tiruan yaitu desain gigi tiruan yang tepat sesuai indikasi pembuatan yang ditentukan berdasarkan klasifikasi kehilangan gigi. Penentuan klasifikasi sebagai gambaran pola kehilangan gigi yang dilakukan secara kurang tepat bisa berdampak pada penentuan indikasi perawatan gigi tiruan serta desainnya yang kurang tepat pula. Pasien akan merasa tidak nyaman dan bahkan dapat menimbulkan 
kerusakan pada gigi asli ataupun jaringan mulut yang masih tinggal. ${ }^{3}$

\section{BAHAN DAN METODE PENELITIAN}

Penelitian ini menggunakan metode deskriptif dengan pendekatan potong lintang yang dilakukan pada masyarakat Desa Roong Kecamatan Tondano Barat. Metode pengambilan sampel pada penelitian ini dengan total sampel. Instrumen yang digunakan ialah kuesioner.

Populasi penelitian ini ialah seluruh masyarakat desa Roong yang menggunakan gigi tiruan sebagian lepasan berbasis akrilik yang berjumlah 75 orang, diperoleh berdasarkan survei awal pada bulan
Oktober 2014.

Data dianalisis dengan analisis univariat menggunakan program Microsoft Excel dan disajikan dalam bentuk tabel.

\section{HASIL PENELITIAN}

Jumlah responden yang diteliti yaitu 75 orang. Dari hasil penelitian diperoleh jumlah responden terbanyak yaitu usia lansia 60-69 tahun berjumlah 23 responden (30,67\%), dan dengan jumlah terkecil usia 20-29 tahun yaitu 8 responden (10,67\%). Jumlah responden yang berjenis kelamin perempuan lebih banyak dibandingkan laki-laki yaitu 49 orang (65,33\%).

Tabel 1. Distribusi frekuensi subjek penelitian berdasarkan kehilangan gigi dan pola kehilangan gigi pada rahang atas dan rahang bawah.

\begin{tabular}{cccccc}
\hline \multirow{2}{*}{ Distribusi Frekuensi } & \multicolumn{2}{c}{ RA } & \multicolumn{2}{c}{ RB } \\
\cline { 2 - 6 } & & $\mathrm{n}$ & $\%$ & $\mathrm{n}$ & $\%$ \\
\hline \multirow{2}{*}{ Kehilangan Gigi } & Ada & 56 & 74,67 & 61 & 81,33 \\
Total & Tidak & 19 & 25,33 & 14 & 18,67 \\
Pola Kehilangan & & 75 & 100 & 75 & 100 \\
Gigi & Sebagian & 28 & 50 & 49 & 80,33 \\
\hline Total & Seluruh & 28 & 50 & 12 & 19,67 \\
\hline & & 75 & 100 & 75 & 100 \\
\hline
\end{tabular}

Tabel 2. Distribusi frekuensi penggunaan gigi tiruan rahang atas pada masyarakat desa Roong.

\begin{tabular}{cccccccccc}
\hline \multirow{2}{*}{$\begin{array}{c}\text { Pola Kehilangan } \\
\text { Gigi }\end{array}$} & \multicolumn{4}{c}{ Penggunaan Gigi Tiruan Rahang Atas } & \multirow{2}{*}{ Total } \\
\cline { 2 - 8 } & \multicolumn{2}{c}{ GTSL } & \multicolumn{3}{c}{ GTC } & \multicolumn{2}{c}{ GTP } & \multicolumn{2}{c}{} \\
\cline { 2 - 9 } & $\mathrm{N}$ & $\%$ & $\mathrm{n}$ & $\%$ & $\mathrm{n}$ & $\%$ & $\mathrm{~N}$ & $\%$ \\
\hline Sebagian & 20 & 35,67 & 8 & 14,33 & - & - & 28 & 50 \\
Seluruh & - & - & - & - & 28 & 50 & 28 & 50 \\
\hline Total & 20 & 35,67 & 8 & 14,33 & 28 & 50 & 56 & 100 \\
\hline
\end{tabular}

Tabel 3. Distribusi frekuensi penggunaan gigi tiruan rahang bawah pada masyarakat desa Roong di rahang bawah.

\begin{tabular}{|c|c|c|c|c|c|c|c|c|}
\hline \multirow{3}{*}{$\begin{array}{c}\text { Pola Kehilangan } \\
\text { Gigi }\end{array}$} & \multicolumn{6}{|c|}{ Penggunaan Gigi Tiruan di Rahang Bawah } & \multirow{2}{*}{\multicolumn{2}{|c|}{ Total }} \\
\hline & \multicolumn{2}{|c|}{ GTSL } & \multicolumn{2}{|c|}{ GTC } & \multicolumn{2}{|c|}{ GTP } & & \\
\hline & $\mathrm{N}$ & $\%$ & $n$ & $\%$ & $\mathrm{n}$ & $\%$ & $\mathrm{~N}$ & $\%$ \\
\hline Sebagian & 39 & 64 & 10 & 16,33 & - & - & 49 & 80,33 \\
\hline Seluruh & - & - & - & - & 12 & 19,67 & 12 & 19,67 \\
\hline Total & 39 & 64 & 10 & 16,33 & 12 & 19,67 & 61 & 100 \\
\hline
\end{tabular}


Mangkat, Wowor, Mayulu: Pola kehilangan gigi...

Tabel 4. Distribusi frekuensi jenis gigi tiruan yang digunakan masyarakat desa Roong di rahang bawah

\begin{tabular}{|c|c|c|c|c|c|c|c|c|}
\hline \multirow{3}{*}{ Rahang } & \multicolumn{6}{|c|}{ Jenis Penggunaan Gigi Tiruan } & \multirow{2}{*}{\multicolumn{2}{|c|}{ Total }} \\
\hline & \multicolumn{2}{|c|}{ GTSL } & \multicolumn{2}{|c|}{ GTC } & \multicolumn{2}{|c|}{ GTP } & & \\
\hline & $\mathrm{N}$ & $\%$ & $\mathrm{n}$ & $\%$ & $\mathrm{n}$ & $\%$ & $\mathrm{~N}$ & $\%$ \\
\hline RA & 20 & 17,10 & 8 & 6,84 & 28 & 23,93 & 56 & 47,86 \\
\hline $\mathrm{RB}$ & 39 & 33,33 & 10 & 8,54 & 12 & 10,26 & 61 & 52,14 \\
\hline Total & 59 & 50,43 & 18 & 15,38 & 40 & 34,19 & 117 & 100 \\
\hline
\end{tabular}

Tabel 5. Distribusi frekuensi pola kehilangan gigi sebagian subjek penelitian berdasarkan klasifisikasi Applegate-Kennedy pada rahang atas dan rahang bawah.

\begin{tabular}{ccccccc}
\hline $\begin{array}{c}\text { Pola kehilangan gigi } \\
\text { (Klasifikasi Applegate- } \\
\text { Kennedy }\end{array}$ & $\mathrm{N}$ & $\%$ & $\mathrm{~N}$ & $\%$ & $\mathrm{~N}$ & $\%$ \\
\hline Klas I & 3 & 10,71 & 8 & 16,33 & 11 & 14,29 \\
Klas II & 2 & 7,14 & 9 & 18,38 & 11 & 14,29 \\
Klas III & 4 & 14,28 & 8 & 16,33 & 12 & 15,58 \\
Klas IV & 5 & 17,86 & 11 & 22,44 & 16 & 20,78 \\
Klas V & 5 & 17,86 & 5 & 10,20 & 10 & 12,98 \\
Klas VI & 9 & 32,14 & 8 & 16,33 & 17 & 22,08 \\
\hline Total & 28 & 36,34 & 49 & 63,64 & 77 & 100 \\
\hline
\end{tabular}

\section{BAHASAN}

Berdasarkan kelompok usia, masyarakat yang mengalami kehilangan gigi di desa Roong Kecamatan Tondano terbanyak adalah kelompok usia 60-69 tahun (30,7\%). Pada usia lanjut (lansia) prevalensi kehilangan gigi memiliki prevalensi yang tinggi. Resesi gingiva, hilangnya perlekatan periodontal dan tulang alveolar merupakan perubahan jaringan periodontal yang umum ditemukan pada lansia yang dapat merupakan faktor risiko terjadinya kehilangan gigi pada lansia. Penelitian ini sejalan dengan hasil yang diperoleh lewat penelitian MedinaSolis dkk. menyatakan semakin meningkat umur, maka kehilangan gigi akan semakin banyak pada rongga mulut. Hal ini disebabkan adanya karies gigi dan penyakit periodontal yang merupakan alasan hilangnya gigi, dimana kedua faktor tersebut akan bertambah parah seiring dengan meningkatnya umur. ${ }^{7}$

Berdasarkan hasil penelitian karakteristik 75 sampelyang berasal dari masyarakat yang mengalami kehilangan gigi di desa Roong kecamatan Tondano Barat, diperoleh hasil terbanyak berjenis kelamin perempuan dibandingkan laki-laki, yaitu sebanyak 65,3\%. Hal ini disebabkan penelitian dilakukan pada hari kerja, sehingga ketika peneliti dan tim berkunjung ke rumah-rumah penduduk, yang lebih banyak dijumpai yakni para ibu rumah tangga. Para lelaki kebanyakan sedang bekerja, baik sebagai petani, pedagang maupun PNS.

Penelitian O’Mullane dkk menunjukkan bahwa perempuan paling banyak mengalami kehilangan gigi, tetapi belum ada kejelasan sampai sekarang mengenai hal ini. Penelitian Corbet dkk menyatakan bahwa perempuan memiliki sedikit resiko penyakit periodontal tetapi besar kemungkinan resiko untuk karies yang dapat menyebabkan kehilangan gigi. ${ }^{8}$

Hasil penelitian mengenai persentase pengguna protesa di Indonesia oleh Agtini ${ }^{9}$ berdasarkan jenis kelamin menunjukan bahwa pada kelompok jenis kelamin perempuan index MT (Missing-Teeth) sebesar 5,1\% dan laki-laki sebesar 4,6\%. 
Hasil penelitian selanjutnya menunjukkan bahwa rahang bawah lebih banyak mengalami kehilangan gigi dari pada rahang atas (Tabel 3). Hasil penelitian yang sama juga di peroleh pada penelitian yang dilakukan oleh Sanya dkk. ${ }^{10}$ Penelitian tersebut menunjukkan kehilangan gigi di rahang bawah lebih tinggi dibandingkan di rahang atas dengan data kehilangan gigi molar rahang bawah yang paling tinggi dibandingkan gigi yang lainnya. Angka kehilangan gigi paling tinggi pada rahang bawah, menurut penulis disebabkan karena gigi permanen yang pertama kali erupsi terjadi di rahang bawah. Hal ini sejalan dengan penelitian yang dilakukan oleh Prabhu dkk bahwa gigi molar permanen rahang bawah adalah gigi yang pertama erupsi di rongga mulut sehingga memungkinkan persentase karies yang tinggi dan kemungkinan diekstraksi akan lebih besar. ${ }^{11}$

Hasil penelitian pada Tabel 4 juga menunjukkan kehilangan gigi sebagian lebih banyak terjadi dibandingkan kehilangan gigi seluruhnya dan pada kehilangan gigi sebagian, lebih banyak terjadi pada rahang bawah. Kehilangan gigi sebagian lebih banyak dibandingkan kehilangan seluruh, karena bila dilihat usia responden hanya 30,67\% yang tergolong usia lansia. Semakin meningkatnya usia prevalensi kehilangan gigi akan semakin besar. Hasil penelitian menunjukkan gigi tiruan yang paling banyak dibutuhkan untuk menggantikan gigi yang hilang yaitu GTSL. Hal ini dikarenakan usia responden bervariasi dari usia 20 tahun hingga 69 tahun dan kelompok usia di bawah lansia merupakan jumlah terbesar dan prevalensi kehilangan gigi meningkat seiring bertambahnya usia.

Hasil penelitian pada penelitian persentase pengguna protesa di Indonesia oleh Agtini $^{9}$ berdasarkan usia menunjukan bahwa index MT (Missing-Teeth) pada kelompok usia $<30$ tahun ialah sebesar 3,4\%, usia 35-44 tahun ialah 4,66\% dan usia 65 tahun ialah 18,3\%.

Data hasil penelitian pada Tabel 2 dan 3 menggambarkan data penggunaan gigi tiruan. Tabel 2 menunjukkan bahwa penggunaan gigi tiruan sebagian lepasan dan gigi tiruan penuh pada rahang atas berimbang (50\%) dan dari data penggunaan gigi tiruan sebagian lepasan, penggunaan gigi tiruan cekat paling rendah $(14,33 \%)$.

Data pada Tabel 3 menunjukkan penggunaan gigi tiruan sebagian lepasan pada rahang bawah paling tinggi (70,33\%) dibandingkan penggunaan gigi tiruan penuh (19,67\%). Data penggunaan gigi tiruan yang paling rendah di rahang bawah, yakni penggunaan gigi tiruan cekat $(16,33 \%)$.

Secara keseluruhan (Tabel 4) menggambarkan penggunaan gigi tiruan dan GTSL merupakan jenis gigi tiruan yang paling banyak digunakan (50,43\%). Gigi tiruan yang paling sedikit digunakan yaitu jenis gigi tiruan cekat (15,38\%). Hal ini sesuai dengan penelitian Ariyani pada masyarakat Padang Bulan Kecamatan Medan Baru, persentase responden yang menggunakan gigi tiruan paling tinggi yaitu GTSL $(39,13)$, serta diikuti GTC dan GTP dengan jumlah yang sama $(30,43 \%)^{3}$

Jenis GTP lebih banyak jumlahnya dibandingkan dengan jenis gigi tiruan cekat. Hal ini di sebabkan karena faktor usia yang semakin tua (lansia) yang mempengaruhi status gizi yang mengakibatkan penyusutan jaringan tulang alveolar, kondisi gigi yang mudah goyang akibat resorbsi tulang alveolar, status pendidikan yang kurang baik yang menyebabkan kesadaran atau pengetahuan tentang menjaga kesehatan rongga mulut yang kurang baik, pola hidup masyarakat yang kurang baik, dan hanya sedikit dari masyarakat yang menyadari bahwa gigi asli dapat dipertahankan selama hidup. Adanya upaya pencegahan, bahan restorasi yang lebih baik pada perawatan konservasi dan endodontik menyebabkan terjadinya penurunan insiden yang dapat menyebabkan kehilangan seluruh gigi.

Pada kehilangan gigi sebagian dengan klasifikasi kelas IV dan kelas VI memiliki 
indikasi untuk pembuatan gigi tiruan sebagian lepasan maupun gigi tiruan cekat. Hasil yang diperoleh menunjukkan indikasi pemakaian gigi tiruan sebagian lepasan atau gigi tiruan cekat pada rahang atas untuk kasus kelas IV dan VI sebanyak 14 kasus, sedangkan jumlah kasus pada rahang bawah sebanyak 19 kasus.

Data pada Tabel 5 menunjukkan penggunaan gigi tiruan cekat pada rahang atas hanya sebanyak 8 kasus sedangkan pada rahang bawah hanya sebanyak 10 kasus. Hasil ini menggambarkan bahwa penggunaan gigi tiruan cekat rendah. Keadaan ini mungkin disebabkan karena pembuatan gigi tiruan cekat memerlukan biaya yang lebih mahal dibandingkan pembuatan gigi tiruan lepasan.

Berdasarkan data yang penulis temukan di lapangan menunjukkan kondisi sosial ekonomi masyarakat desa Roong rata-rata golongan menengah ke bawah dengan sumber mata pencaharian pada umumnya sebagai petani serta nelayan. Pembuatan gigi tiruan cekat yang relatif membutuhkan waktu yang lebih lama dibandingkan pembuatan gigi tiruan lepasan di daerah Sulawesi Utara, mungkin juga dapat menjadi alasan rendahnya penggunaan gigi tiruan cekat pada kondisi kehilangan gigi sebagian. Waktu pembuatan gigi tiruan cekat yang lebih lama bisa disebabkan karena di desa Roong maupun kabupaten Minahasa Induk belum memiliki laboratorium pembuatan gigi tiruan yang lengkap, sehingga pembuatan gigi tiruan cekat harus dilakukan di luar daerah.

Pola kehilangan gigi yang ditemukan pada penelitian ini sebagian besar merupakan indikasi untuk GTSL seperti klas I, II, III, IV, dan V. Sebenarnya klasifikasi klas IV dan VI yang banyak ditemukan,juga merupakan indikasi untuk penggunaanGTC. Namun hal ini seringkali sulit karena sering ditemukan faktor-faktor yang menjadi kontraindikasi pemasangan GTC, di antaranya gigi tetangga sudah tidak mampu mendukung, kebersihan mulut pasien kurang, penyakit periodontal yang parah sehingga tidak memungkinkan untuk dilakukan pemasangan GTC.

Berdasarkan pola kehilangan gigi pada rahang atas dan rahang bawah pola kehilangan gigi sebagian paling banyak ditemukan, sedangkan berdasarkan klasifisikasi Applegate-Kennedy ditemukan kelas VI yang paling banyak. Hal ini disebabkan gigi posterior pada kedua sisi rahang memiliki fungsi pengunyahan sehingga secara fungsional lebih banyak digunakan dari pada gigi anterior yang memiliki fungsi untuk memotong makanan dan estetis. ${ }^{12}$ Lokasi gigi posterior juga lebih sulit untuk dibersihkan sehingga lebih mungkin untuk terjadi kerusakan yang akhirnya menyebabkan gigi harus dicabut. ${ }^{13}$

\section{SIMPULAN}

Berdasarkan hasil penelitian tentang gambaran pola kehilangan gigi pada pengguna gigi tiruan di desa Roong kecamatan Tondano Barat Minahasa Induk, dapat disimpulkan:

1. Kehilangan gigi kebanyakan terjadi pada rahang bawah yaitu kehilangan gigi sebagian.

2. Pada kasus kehilangan gigi, penggunaan terbanyak jenis GTSL dengan jumlah 50,43\% (rahang atas $17,10 \%$, rahang bawah 33,33\%).

3. Pola kehilangan gigi sebagian berdasarkan klasifisikasi ApplegateKennedy, terbesar kelas VI sebanyak $22,10 \%$ (rahang atas 32,14\% dan rahang bawah 16,33\%)

4. Penggunaan GTSL berdasarkan pola kehilangan gigi, terbesar kelas VI sebanyak 22,10\% (GTSL rahang atas $32,14 \%$ dan rahang bawah 16,33\%)

5. Penggunaan GTC berdasarkan pola kehilangan gigi, terbesar klas IV sebanyak 27,27\% (GTC rahang atas 1 orang $(5,55 \%)$

\section{SARAN}

1. Bagi Pemerintah, dalam hal ini Dinas Kesehatan kiranya lebih memperhatikan kesehatan gigi dan mulut pada masyarakat melalui program-program 
yang bisa langsung menjangkau masyarakat.

2. Bagi Masyarakat untuk lebih memerhatikan pemeliharaan kesehatan gigi dan mulut, agar tidak lebih banyak lagi mengalami kehilangan gigi, dan juga untuk sesegera mungkin berusaha menggantikan gigi yang hilang dengan gigi tiruan yang tepat untuk menggantikan fungsi-fungsi gigi yang hilang dan tidak menimbulkan hal-hal yang terjadi akibat tidak mengganti gigi yang hilang.

3. Bagi Institusi dan akademisi yang terkait untuk mengadakan penelitian untuk mengetahui penyebab dan pola kehilangan gigi yang terjadi pada masyarakat dan kendala yang terdapat pada masyarakat yang tidak langsung mengganti gigi yang hilang dengan gigi tiruan yang tepat.

\section{DAFTAR PUSTAKA}

1. Jayasingha RM, Tilakaratne A, Amarasena N, Mack F, Anandamoorthy T. Impact of marginal contact of removable acrylic partial dentures on periodontal parameters. International Journal of Research in Medical and Health Sciences April 2013;1(3):1-11.

2. Departemen Kesehatan Republik Indonesia. Laporan riset kesehatan dasar nasional 2010. Jakarta: Badan penelitian dan pengembangan kesehatan. 2011.

3. Esan TA, Olusile AO, Akeredolu PA, Esan AO. Socio-demographic factors and edentulism the Nigerian experience. BMC Oral Health 2004; 4(3):1-6.

4. Millar WJ, Locker D. Edentulism and denture use. Health Reports 2005;
17(1): 55-8.

5. Medina-Solis CE, Perez-Nunez R, Maupome G, Casanova-Rosado JF. Edentulism among Mexican adults aged 35 years and older and associated factors. Am J Public Health 2006; 96(9):1578-81.

6. Lin HC, Corbet EF, Lo ECM, Zhang HG. Tooth loss, occluding pairs, and prosthetic status of Chinese adults. J Dent Res 2001;80(5):1491-95.

7. Medina-Solis CE, Perez-Nunez R, Maupome G, Casanova-Rosado JF. Edentulism among Mexican adults aged 35 years and older and associated factors. Am J Public Health 2006;96(9):1578-81.

8. Lin HC, Corbet EF, Lo ECM, Zhang HG. Tooth loss, occluding pairs, and prosthetic status of Chinese adults. J Dent Res 2001;80(5):1491-95.

9. Agtini MD. Persentase pengguna protesa di Indonesia. Medi Litbang Kesehatan. 2010;20(2):50-8.

10.Sanya BO, Ng'ang'a PM, Ng'ang'a RN. Causes and pattern of missing permanent teeth among Kenyans. East African Medical Journal. 2004; 81(6):322.

11.Prabhu N, Kumar S, D’souza M, Hegde V. Partial edentulousness in a rural population based on Kennedy's classification: An epidemiological study. J Prosthodont 2009;9:18-23.

12.Indonesian e-dental Information. Kehilangangigi. Januari 2009. $<$ http://www.geocities.com/sjuhada/k ehilangangigi.html $>$ (cited 12 April 2010).

13.Douglass CW, Watson AJ. Future needs for fixed and removable partial denture in the United States. J Prosthet Dent 2002;87:9-14. 